\title{
A New Era for Our
}

\section{Fellow Creatures}

Andrés Arias Rodríguez

Uníversidad de Ovíedo

Correspondence | ariasandres@uniovi.es

Citation | Arias Rodriguez, Andrés. “A New Era for Our Fellow Creatures.” Journal of Big History IV, no. 1: 67-68, doi:

http://dx.doi.org/10.22339/jbh.v4i1.4120.

DOI | http://dx.doi.org/10.22339/jbh.v4i1.4120

Christine M. Korsgaard is a renowned philosopher who has taught at Harvard University for almost three decades. She works on moral philosophy, interpretations of ethical theory, the works of Immanuel Kant, and the ethics surrounding our treatment of animals. This is her first book that addresses the treatment of animals.

Fellow Creatures: Our Obligations to the Other Animals has been brewing since the author became a vegetarian several years ago. This became her reason, her motivation for writing about the ethical treatment of animals. Animals have changed the course of human history. They have provided food, shelter and clothing, companionship, and labor; they have worked for us; they have even fought for us. Without them our history would have been far less certain and it is unlikely that advanced civilization would have developed. Yet our current society seems to have forgotten how much we owe to animals. I fully subscribe to the author's belief that "the way human beings now treat the other animals is a moral atrocity of enormous proportions" (p. xi). In clear language, and in a style suitable for nonspecialists, Korsgaard presents her passionate moral views and her reasoned, objective philosophical arguments, on this controversial topic.

In Fellow Creatures she establishes her argument in the framework of two philosophical commitments: 1) Kant's ethics, which effectively support the

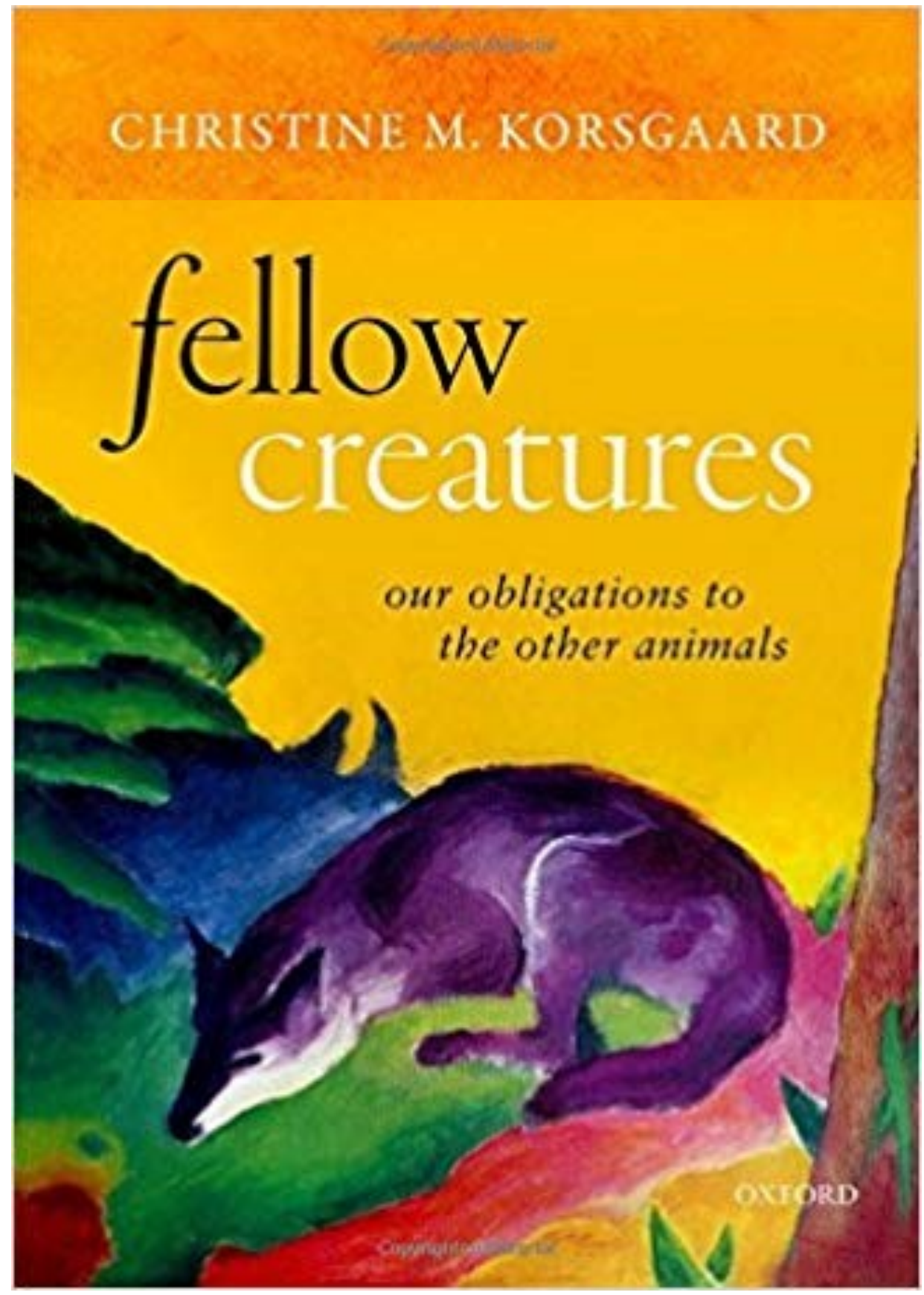


notion of animal rights and the concomitant idea that we, therefore, have obligations toward them; and 2) a particular point of view derived from the theory of Aristotle about why some things are good and others bad. She defends as her core thesis the basic correctness of Kant's account of why we have obligations to animals, although she admits that Kant himself did not explicitly endorse this idea as explicitly as she does here. Thus, Korsgaard argues that the common understanding of Kant's general theory-i.e. the notion that animals are non-rational, unselfconscious beings (thus giving them no rights) is mistaken, and that Kantian philosophical terms do not necessarily exclude animals from being ends in themselves. "Even within the framework of Kant's theory," she writes, "it is possible that rational beings legislate moral laws whose protections extend to other animals. . . . We rational beings must claim the standing of an 'end-initself not only for ourselves, but for the other animals as well" (131).

Korsgaard goes on to explain how she sees Kant's ethics as leading to the conclusion that animals are not mere means to human ends, but ends in their own right. She does not support Kant's notion that our duties to animals are indirect; instead, she believes that our obligations to other animals-although not exactly the same as our obligations to other people"arise from the relations to ourselves" (XI). She feels that "Valuing", with a capital letter, is an original activity of Life, i.e., an important characteristic of a sentient being's relationship to itself.

Throughout most of the chapters of this book-parts I and II-the author reels off these ideas and others derived from them, aiming to defend her interpretive view of Kant's ethics. Although these sections are heavily theoretical, they provide nonspecialist readers, even those without a strong background in philosophy, the opportunity to immerse themselves in Kantian ethics and to acquire some basic knowledge that will surely help them to understand debates about the treatment of animals from an ethical point of view. Korsgaard explains in great detail her proposed terminology, covering all the necessary key concepts, like "creatures," for example, which she uses to refer jointly to both humans and other animals, or the term "companion animal," instead of "pet," the latter of which she considers demeaning.

All together her use of terminology, her ethics, and her general approach are convincing and will cause any reader to sympathize with her arguments and her point of view. In addition, Korsgaard explores evolution, extinction, senescence, and other topics that are an added value in this book. She even takes a look at the socalled "immortal jellyfish" (Turritopsis dohrnii), which is one of the few known cases of animals capable of reverting completely to a sexually immature, colonial stage after having reached sexual maturity as a solitary individual.

The final part of the book-part III, the last three chapters-deals with more practical issues, which, as such, are far more accessible to the general reader, as well as those who come from the natural sciences. Here Korsgaard offers her insightful vision on controversial issues like eating meat and using animal products that require us to kill animals or make them suffer; the abolishing the treat- ment of animals as pets; and using of working animals, animals in the military, or the animals in scientific experiments. At this critical juncture, she argues that one needs a good reason to kill or harm an animal, and often we do not have it. She considers that all situations that involve the treatment of animals as a mere means to our ends are morally wrong, concluding that the "fundamental wrong is the system that allows us to view animals as our resources, here for us" (220). Further topics she addresses with clever insight and good judgment are of an ecological nature and have environmental implications, i.e., the value of the species, communities, the habitat loss and the biodiversity crisis. In her own words, "ecosystems, and even the world biosphere, nature itself, have intrinsic value, and [. . .] the value of a species consists in its contribution to those" (192).

This amazing book represents a great opportunity for a specialized and non-specialized audience to dive into animal ethics and the ethical treatment of animals and to ascertain how the philosophical reflection can help us to provide a more robust response to a current, pressing problem in our society. Hopefully, this book may serve to raise awareness worldwide about animal cruelty and presently neglected animal rights, making us one step away from ushering in a new era for our fellow creatures.

\section{Reference}

Korsgaard, Christine M. Fellow Creatures: Our Obligations to the Other Animals. New York: Oxford University Press, 2018. 